\section{Australian Journal of \\ Crop Science}

\title{
Effect of spacing on mini watermelon hybrids grown in a protected environment
}

\author{
Rafaelle F Gomes $^{1 *}$, Lucas S Santos ${ }^{2}$, Marcus V Marin ${ }^{2}$, Guilherme M M Diniz ${ }^{2}$, Hudson de Oliveira \\ Rabelo $^{2}$, Leila Trevisan Braz ${ }^{2}$
}

\author{
${ }^{1}$ Universidade Federal Rural da Amazônia - Campus Capanema, Rua João Pessoa, n ${ }^{\circ 21}$, Centro, 68700-030, \\ Capanema-PA, Brasil \\ ${ }^{2}$ Universidade Estadual Paulista - Campus Jaboticabal, Via de Acesso Prof. Paulo Donato Castellane, s/n, Zona \\ Rural,14884-900, Brasil
}

\author{
*Corresponding author: rafaelle.fazzi@yahoo.com.br
}

\begin{abstract}
In recent years, a group of small watermelons has stood out with $1-3 \mathrm{~kg}$ in weight called mini watermelons. These watermelons, when grown under greenhouse conditions, require different management techniques. This study evaluated the performance of mini watermelon hybrids at different plant spacing. To this end, the experiments were conducted in a greenhouse using a substrate of coconut husk fibers with fertigation. The study design was a randomized block with $5 \times 3$ factorial treatments and four replicates. The factors evaluated included five mini watermelon hybrids (Beni Kodama, Ki Kodama, Smile, New Kodama, and Beni Makura) and three plant spacing configurations $\left(E_{1}=0.35 \mathrm{~m}, \mathrm{E}_{2}=0.50 \mathrm{~m}\right.$, and $\left.\mathrm{E}_{3}=0.65 \mathrm{~m}\right)$. Growth characteristics, production, and quality were evaluated using analysis of variance. There was no significant interaction between the hybrids and plant spacing for yield traits, physiological traits, and fruit quality. Fresh fruit mass, yield, transverse and longitudinal diameter and firmness presented significant differences for both factors, type of hybrid and plant spacing. In this study, despite the established competition in terms of spacing, the performance of hybrids was not negatively affected. Thus, we recommend the cultivation of hybrids spaced $0.50 \mathrm{~m}$ apart in coconut husk fibers, because it results in good yield and fruit quality, while facilitating plant management techniques.
\end{abstract}

Keywords: Citrullus lanatus; planting density; mini vegetables; coconut fibers; competition.

Abbreviations: A_Net photosynthetic rate; LAI_Leaf area index; SS_Soluble solids; TA_Titratable acidity; SS/TA_Maturation index.

\section{Introduction}

Watermelon, Citrullus lanatus (Thunb.) Matsum. \& Nakai, from the family Cucurbitaceae, is the most cultivated species worldwide and is an economically and socially important species in many regions. In addition, watermelon fruits have desirable nutritional and therapeutic features, rendering them attractive to consumers (Dias et al., 2006).

Watermelon is cultivated in different regions of Brazil, with São Paulo State being the fourth largest national producer. In 2014, the area in the state cultivated with watermelon occupied 6,664 ha, and the productivity was estimated to be $27.30 \mathrm{t} \mathrm{ha}^{-1}$ (IEA, 2014). According to the data presented in the Brazilian Yearbook of Agricultural Production (Agrianual, 2015), 60,973 tons of watermelon were commercialized at the São Paulo Warehouse and Storehouse Company (CEAGESP) from January to July 2014, representing approximately $2.97 \%$ of national production for that year.

Brazilian consumers' preference is based on fruit size and shape, flesh color, soluble solids, and the presence or absence of seeds (Ramos et al., 2009). A new type of watermelon, the mini watermelons, was developed by seed companies in response to the market demand for fruits with smaller size and high quality.

The mini watermelons, also known as "ice box" or "refrigerator watermelons" are designed for consumers with high purchasing power. These cultivars are mostly hybrids and usually produce fruits with weights ranging from 1 to 3 $\mathrm{kg}$. These hybrid cultivars have shorter growing season, can be planted in tighter spacing, and smaller fruits facilitate their transport.

Hybrids of the common watermelon have been traditionally planted in Brazil because of their higher fruit quality and yield. The advantages of using watermelon hybrids include heterosis or hybrid vigor, higher uniformity and adaptability, early flowering time, and disease and pest resistance.

Traditionally, watermelons are cultivated in fields and the plants grow on the ground (Seabra Junior et al., 2003). However, to meet the different market demands for quality, modern production technologies have been developed, such as cultivation in greenhouses, and new hybrid cultivars have been developed with stem training systems, especially the vertical system, in association with a suitable stem pruning management.

The vegetative growth is important for growers because, when associated to fecundity, it may facilitate the choice of the most suitable plant density; high density negatively affects plant growth (Resende and Costa, 2003) and directly affects fruit size and productivity.

The management of the number of plants per area is essential to obtain the highest number of fruits with commercial traits, given the fact that the reduction of plant spacing may increase productivity and decrease the mean 
fruit weight (Kultur et al., 2001; Goreta et al., 2005); the latter can be sometimes desirable to serve different market demands. Plant stem training facilitates the application of pesticides, ventilation, and distribution of light. It also makes possible the use of denser plant systems, which produce a relatively higher number of fruits per area (Silva et al., 1998). This work aimed to evaluate the performance of mini watermelon hybrids (Beni Kodama, Ki Kodama, Smile, New Kodama, and Beni Makura) cultivated in husk coconut fiber at different plant spacing in a greenhouse. In here, we sought to improve the cropping techniques, which may bring benefits to growers specialized in producing fruits with high quality and unique characteristics to meet special market demands.

\section{Results and Discussion}

\section{Plant production}

No significant interaction between the main factors, i.e., the type of hybrid and plant spacing was found. Therefore, both factors were analyzed separately (Table 1).

The shoot dry mass was not statistically different between the hybrids and the different spacing configurations. These results contradict the commonly accepted finding that increase in planting density reduces plant growth through competition for water, light, and nutrients. It is possible that the shoot dry mass was not affected by planting density ( 3.57 , 2.5, and 1.92 plants $\mathrm{m}^{-2}$ ) due to uniform application of nutrients via fertigation, combined with genetic similarity of the hybrids. These results were consistent with those reported by Ramos et al. (2009) and Campagnol et al. (2012) for mini watermelons.

No significant differences in leaf area were observed between the hybrids tested (Table 1); the greatest mean leaf area was obtained for Beni Makura $\left(7395.29 \mathrm{~cm}^{2}\right.$ plant $\left.{ }^{-1}\right)$. However, significant differences were observed in leaf area between plants cultivated at different spacing configurations; the greatest leaf area $\left(7337.57 \mathrm{~cm}^{2}\right.$ plant $\left.{ }^{-1}\right)$ was recorded for plants grown with spacing of $0.50 \mathrm{~m}\left(2.50\right.$ plants $\left.\mathrm{m}^{-2}\right)$, although it was not statistically different from the leaf area $\left(7114.19 \mathrm{~cm}^{2}\right.$ plant $\left.^{-1}\right)$ recorded for plants with spacing of 0.65 $\mathrm{m}\left(1.92\right.$ plants $\left.\mathrm{m}^{-2}\right)$. It was hypothesized that lower planting density provides more space to the plants to expand their leaves and reduces shading from surrounding plants. Thus, there is increased light interception per plant and, consequently, greater individual growth (Papadopoulos and Pararajasingham, 1997, Andriolo et al., 2004, Peil et al., 2014).

The leaf area index (Table 1) did not differ significantly among the hybrids. However, the spacing of $0.35 \mathrm{~m}(3.57$ plants $\mathrm{m}^{-2}$ ) produced the greatest leaf area index (5.12) and was statistically different from other spacing configurations. Campagnol et al. (2012), in their study on the influence of training systems and plant density on mini watermelon cultivation, observed that denser spacing among plants results in higher leaf area index. According to Malik et al. (2004), this behavior is attributed to the fact that as the leaf area index increases, the leaves closer to the ground are covered by shade, resulting in lower mean photosynthetic rate of the entire leaf area. This can be interpreted by the fact that the greater leaf area exposed to the sun, the more plant dry mass produced per day and the higher the culture growth rate. Considering the net photosynthesis, there were no significant differences between the hybrids and between the different spacing configurations (Table 1). The overall mean net photosynthetic rate was estimated to be $9.11 \mu \mathrm{mol} \mathrm{m}^{-2} \mathrm{~s}^{-1}$.
The optimal density (i.e., the population of plants able to optimally utilize available resources) depends on several factors, including the genotype, environment, and crop management strategy. However, although planting density influences the growth variables, there were no changes in the photosynthetic rate in this study. These results were in contrast to those reported by Sangoi et al. (2003). Increase in planting density is a way to maximize the interception of solar radiation; nevertheless, it may reduce the photosynthetic activity of crops and their efficiency for photoassimilate conversion.

Significant differences in fresh-fruit weight were observed among the hybrids (Table 1). The hybrids Smile and New Kodama produced fruits with the greatest mean weight of $2.45 \mathrm{~kg}$ and $2.33 \mathrm{~kg}$, respectively. The spacing of $0.65 \mathrm{~m}$ (1.92 plants $\mathrm{m}^{-2}$ ) produced fruits with the greatest mean weight of $2.27 \mathrm{~kg}$, although it was not statistically different from that $(2.14 \mathrm{~kg})$ observed in plants at spacing of $0.50 \mathrm{~m}$. These results are consistent with the findings of Campagnol et al. (2012) and Peil et al. (2014), who reported that increase in planting density and reduction of solar radiation decrease the individual and top-shoot leaf area means. This, in turn, results in lower interception of solar radiation, carbon dioxide absorption, and consequently lower mean fruit mass. Thus, as spacing between plants increases, fruit development rate increases due to lower competition for resources associated to plant growth.

Significant differences in yield were observed among the different spacing configurations (Table 1); smaller spacing of $0.35 \mathrm{~m}$ resulted in higher productivity in relation to the larger spacing $\left(62.88 \mathrm{t} \mathrm{ha}^{-1}\right)$. The highest yield obtained at a spacing of $0.35 \mathrm{~m}$ was a result of greater density of plants per area. Although the tighter plant spacing decreased the mean fruit weight, it provided gains in overall productivity, corroborating the results of various studies (Goreta et al., 2005; Gonsalves et al., 2011; Campagnol et al., 2012; Peil et al., 2014) on solanaceous and cucurbit species.

However, it is noteworthy that, even with the linear increase in productivity as a function of tighter spacing, plant cultivation at very high density is not suitable because it hampers management activities, such as it increases the need for pruning, increases the likelihood of fungal and bacterial diseases, and hinders their monitoring and control.

\section{Fruit quality}

Because no significant interaction between the hybrids and spacing was detected for the characters associated to fruit quality (Table 2), both factors were analyzed separately.

The fruit firmness in hybrids Smile and Beni Kodama (11.95 N and $10.86 \mathrm{~N}$, respectively) was greater than that of other hybrids. The greatest fruit firmness of $10.20 \mathrm{~N}$ and 9.76 $\mathrm{N}$ was obtained in plants spaced at $0.50 \mathrm{~m}$ and $0.65 \mathrm{~m}$, respectively. In contrast, Campagnol et al. (2012), who evaluated the stem training systems and planting density of the mini watermelon hybrid Smile in a greenhouse, did not observe significant differences among the densities studied. Nevertheless, it is important to point out that the firmness of the fruit may also be influenced by genetic characteristics of the hybrids, which is consequently reflected in a greater or lower resistance to fruit transportation.

Regarding the titratable acidity (Table 2), there were no significant differences among the hybrids and among the different spacing, with the mean of $6.00 \mathrm{mg}$ citric acid $100^{-1} \mathrm{~g}$ of flesh. Similar trends in acidity were reported in studies by Ramos et al. (2009) and Campagnol et al. (2012), who studied different cultivars and watermelon planting densities, 
Table 1. Means of shoot dry mass (SDM), leaf area (LA), leaf area index (LAI), net photosynthesis (A), fresh fruit mass (FFM), and yield (Y) of mini watermelon hybrids planted at different spacings.

\begin{tabular}{|c|c|c|c|c|c|c|}
\hline Hybrids $(\mathrm{H})$ & $\begin{array}{c}\text { SDM } \\
(\mathrm{g})\end{array}$ & $\begin{array}{c}\text { LA } \\
\left(\mathrm{cm}^{2} \text { plant }^{-1}\right)\end{array}$ & LAI & $\begin{array}{c}\mathrm{A} \\
\left(\mu \mathrm{mol} \mathrm{m} \mathrm{m}^{-2} \mathrm{~s}^{-1}\right)\end{array}$ & $\begin{array}{l}\text { FFM } \\
(\mathrm{kg})\end{array}$ & $\begin{array}{c}\mathrm{Y} \\
\left(\mathrm{t} \mathrm{ha}^{-1}\right)\end{array}$ \\
\hline Beni Kodama & $107.92 \mathrm{a}$ & $7123.80 \mathrm{a}$ & $3.43 \mathrm{a}$ & $8.45 \mathrm{a}$ & $1.79 \mathrm{c}$ & $45.40 \mathrm{a}$ \\
\hline Ki Kodama & $95.83 \mathrm{a}$ & $6329.39 a$ & $2.87 \mathrm{a}$ & $8.78 \mathrm{a}$ & $2.13 \mathrm{abc}$ & $53.59 \mathrm{a}$ \\
\hline Smile & $103.66 \mathrm{a}$ & $7000.82 \mathrm{a}$ & $3.36 \mathrm{a}$ & $8.70 \mathrm{a}$ & $2.45 \mathrm{a}$ & $55.47 \mathrm{a}$ \\
\hline New Kodama & $98.40 \mathrm{a}$ & $6690.98 \mathrm{a}$ & $3.18 \mathrm{a}$ & $9.73 \mathrm{a}$ & $2.33 \mathrm{a}$ & $49.78 \mathrm{a}$ \\
\hline Beni Makura & $105.77 \mathrm{a}$ & $7395.29 \mathrm{a}$ & $3.38 \mathrm{a}$ & $9.88 \mathrm{a}$ & $1.99 \mathrm{bc}$ & $44.84 \mathrm{a}$ \\
\hline F test & $0.63^{\mathrm{ns}}$ & $1.43^{\mathrm{ns}}$ & $2.11^{\mathrm{ns}}$ & $1.58^{\mathrm{ns}}$ & $9.41^{* * *}$ & $2.12^{\mathrm{ns}}$ \\
\hline DMS & 25.77 & 1383.51 & 0.63 & 2.08 & 0.35 & 13.17 \\
\hline \multicolumn{7}{|l|}{ Spacing (E) } \\
\hline $0.35 \mathrm{~m}$ & $92.78 \mathrm{a}$ & $6272.40 \mathrm{~b}$ & $5.12 \mathrm{a}$ & $8.88 \mathrm{a}$ & $2.02 \mathrm{~b}$ & $62.88 \mathrm{a}$ \\
\hline $0.50 \mathrm{~m}$ & $107.59 \mathrm{a}$ & $7337.57 \mathrm{a}$ & $2.93 \mathrm{~b}$ & $8.60 \mathrm{a}$ & $2.14 \mathrm{ab}$ & $46.14 \mathrm{~b}$ \\
\hline $0.65 \mathrm{~m}$ & $106.57 \mathrm{a}$ & $7114.19 \mathrm{ab}$ & $1.68 \mathrm{c}$ & $9.84 \mathrm{a}$ & $2.27 \mathrm{a}$ & $40.42 \mathrm{~b}$ \\
\hline F test & $2.79^{\mathrm{ns}}$ & $4.46^{*}$ & $205.66^{* *}$ & $2.66^{\mathrm{ns}}$ & $3.69^{*}$ & $21.26^{* * *}$ \\
\hline DMS & 17.01 & 913.60 & 0.42 & 1.38 & 0.23 & 8.70 \\
\hline Interaction $\mathrm{H} \times \mathrm{E}$ & $0.38^{\mathrm{ns}}$ & $0.88^{\mathrm{ns}}$ & $1.99^{\mathrm{ns}}$ & $0.94^{\mathrm{ns}}$ & $1.99^{\mathrm{ns}}$ & $0.41^{\mathrm{ns}}$ \\
\hline $\mathrm{CV}(\%)$ & 21.64 & 17.21 & 16.71 & 19.66 & 13.78 & 22.72 \\
\hline
\end{tabular}

The means followed by the same letter in a column did not significantly differ. ${ }^{\text {ns }}$ : not significant; ${ }^{*}$ and ${ }^{* *}$ : significant differences at $\mathrm{P}<0.05$ and $\mathrm{P}<0.01$, respectively; $\mathrm{CV}$ : coefficient of variation (\%); DMS: significant difference minimum.

Table 2. Mean transverse diameter (TD), longitudinal diameter (LD), firmness, titratable acidity (TA), soluble solids (SS), and fruit shape index (FSI) of mini watermelon hybrids planted at different spacings.

\begin{tabular}{|c|c|c|c|c|c|c|}
\hline \multirow[b]{2}{*}{ Hybrids (H) } & TD & LD & Firmness & $\mathrm{TA}$ & $\mathrm{SS}$ & FSI \\
\hline & $(\mathrm{mm})$ & $(\mathrm{mm})$ & $(\mathrm{N})$ & $\begin{array}{c}\text { (mg citric acid } 100^{-} \\
1 \mathrm{~g} \text { squash })\end{array}$ & $\left({ }^{\circ}\right.$ Brix $)$ & \\
\hline Beni Kodama & $143.77 \mathrm{~cd}$ & $161.51 \mathrm{~b}$ & $10.86 \mathrm{ab}$ & $7.00 \mathrm{a}$ & $12.04 \mathrm{a}$ & $1.12 \mathrm{~b}$ \\
\hline Ki Kodama & $149.57 \mathrm{bc}$ & $167.26 \mathrm{~b}$ & $7.98 \mathrm{c}$ & $6.00 \mathrm{a}$ & $10.42 \mathrm{~b}$ & $1.12 \mathrm{~b}$ \\
\hline Smile & $158.61 \mathrm{a}$ & $170.45 \mathrm{~b}$ & $11.95 \mathrm{a}$ & $7.00 \mathrm{a}$ & $10.76 \mathrm{~b}$ & $1.07 \mathrm{c}$ \\
\hline New Kodama & $155.47 \mathrm{ab}$ & $170.46 \mathrm{~b}$ & $7.29 \mathrm{c}$ & $5.00 \mathrm{a}$ & $10.24 \mathrm{~b}$ & $1.09 \mathrm{bc}$ \\
\hline Beni Makura & $140.34 \mathrm{~d}$ & $184.54 \mathrm{a}$ & $10.60 \mathrm{~b}$ & $7.00 \mathrm{a}$ & $12.08 \mathrm{a}$ & $1.31 \mathrm{a}$ \\
\hline F test & $20.07^{* * *}$ & $12.99^{* * *}$ & $37.33^{* * *}$ & $1.72^{\mathrm{ns}}$ & $24.00^{* * *}$ & $158.44^{\text {*** }}$ \\
\hline DMS & 6.90 & 9.49 & 1.32 & 2.00 & 0.73 & 0.03 \\
\hline \multicolumn{7}{|l|}{ Spacing (E) } \\
\hline $0.35 \mathrm{~m}$ & $147.18 \mathrm{~b}$ & $166.95 \mathrm{~b}$ & $9.25 \mathrm{~b}$ & $6.00 \mathrm{a}$ & $10.97 \mathrm{a}$ & $1.14 \mathrm{a}$ \\
\hline $0.50 \mathrm{~m}$ & $149.24 \mathrm{ab}$ & $170.27 \mathrm{ab}$ & $10.20 \mathrm{a}$ & $6.00 \mathrm{a}$ & $11.26 \mathrm{a}$ & $1.14 \mathrm{a}$ \\
\hline $0.65 \mathrm{~m}$ & $152.25 \mathrm{a}$ & $175.32 \mathrm{a}$ & $9.76 \mathrm{ab}$ & $6.00 \mathrm{a}$ & $11.09 \mathrm{a}$ & $1.15 \mathrm{a}$ \\
\hline $\mathrm{F}$ test & $3.70^{*}$ & $5.33^{* *}$ & $3.51^{*}$ & $0.92^{\mathrm{ns}}$ & $1.03^{\mathrm{ns}}$ & $2.16^{\mathrm{ns}}$ \\
\hline DMS & 4.56 & 6.27 & 0.87 & 0.01 & 0.48 & 0.02 \\
\hline Interaction $\mathrm{H} \times \mathrm{E}$ & $0.70^{\mathrm{ns}}$ & $0.93^{\mathrm{ns}}$ & $0.87^{\mathrm{ns}}$ & $1.51^{\mathrm{ns}}$ & $0.27^{\mathrm{ns}}$ & $1.27^{\mathrm{ns}}$ \\
\hline $\mathrm{CV}(\%)$ & 3.96 & 4.77 & 11.63 & 25.76 & 5.66 & 2.33 \\
\hline
\end{tabular}

Table 3. Estimates of the Pearson correlation coefficients based on the means of the evaluated characteristics (EC) production per plant (PP), total productivity (TP), fruit mass (FM), leaf area (LA), leaf area index (LAI), net photosynthesis (A), soluble solids (SS), and fruit shape index (FSI) of mini watermelon hybrids planted at different spacing.

\begin{tabular}{|c|c|c|c|c|c|c|c|}
\hline $\mathrm{EC}$ & PP & TP & FM & LA & LAI & A & SS \\
\hline PP & - & & & & & & \\
\hline PT & $0.55^{\text {** }}$ & - & & & & & \\
\hline MF & $0.34^{* *}$ & $0.34^{* *}$ & - & & & & \\
\hline $\mathrm{AF}$ & $-0.06^{\mathrm{ns}}$ & $-0.31^{*}$ & $0.01^{\mathrm{ns}}$ & - & & & \\
\hline IAF & $-0.32^{*}$ & $0.52^{* *}$ & $-0.26^{*}$ & $0.04^{\mathrm{ns}}$ & - & & \\
\hline A & $0.26^{*}$ & $-0.02^{\mathrm{ns}}$ & $0.09^{\mathrm{ns}}$ & $0.14^{\mathrm{ns}}$ & $-0.10^{\mathrm{ns}}$ & - & \\
\hline SS & $-0.03^{\mathrm{ns}}$ & $-0.09^{\mathrm{ns}}$ & $-0.32^{*}$ & $0.27^{*}$ & $0.02^{\mathrm{ns}}$ & $-0.01^{\mathrm{ns}}$ & - \\
\hline FSI & $-0.27^{*}$ & $-0.26^{*}$ & $-0.19^{\mathrm{ns}}$ & $0.17^{\mathrm{ns}}$ & $-0.05^{\mathrm{ns}}$ & $0.09^{\text {ns }}$ & $0.53^{* *}$ \\
\hline
\end{tabular}


respectively. Acidity that originates from organic acids is an important character in fruit taste. With few exceptions, this acidity decreases proportionally with maturation of the fruits as the acids are converted into sugars in the respiratory processes (Pretty, 1982). The soluble solid content (Table 2) did not show significant difference among the hybrids; the hybrids Beni Kodama and Beni Makura contained the highest levels contents of soluble solids, with the mean of $12{ }^{\circ}$ Brix. Campagnol et al. (2012) studied the planting density, stem training system of mini watermelon and reported the mean value of $10.64^{\circ}$ Brix for the hybrid Smile. Ramos et al. (2009), who evaluated the effect of planting density on the performance and quality of small fruits of watermelon cultivars, reported a soluble solid content of $7.86{ }^{\circ}$ Brix for the same hybrid. According to Dias and Lima (2010) and following the recommendations of the European Union, which established $9{ }^{\circ}$ Brix as the minimal suitable level, the soluble solids contents obtained in the present study are considered acceptable. Brazilian market demands fruits with soluble solid content of at least $10^{\circ}$ Brix. Therefore, the results obtained for all the hybrids indicate that they have good levels of sweetness and comply with consumers' demands. The fruit shape index was statistically different among the hybrids (Table 2), whereas the spacing between plants did not affect the index. Among the tested hybrids, the most uniform and suitable shape index of 1.07 was calculated for the hybrid Smile. The fruit shape index is an indicator of fruit form the closer the values are to 1 , the more spherical the fruits are. The data from other studies (Grangeiro et al., 1999; Pereira et al., 2003; Seabra Junior et al., 2003) show that this ratio can be influenced by planting density, the number of fruits per plant, plant position, and genetic factors. The fruit format index is an important quality attribute in the classification and standardization of fruits, which may affect the acceptance and appreciation of the product in certain markets and interfere with fruit accommodation during packaging (Purquerio and Cecílio Filho, 2005).

\section{Correlation}

The effect of variation in hybrids as a function of spacing on the growth characteristics, production, and quality resulted mainly from the mutual relation between these characteristics, as expressed by Pearson correlations (Table 3 ). The production per plant was positively correlated with total productivity $(0.55)$, fruit weight $(0.34)$, and net photosynthesis $(0.26)$, whereas it was negatively correlated with the leaf area index $(-0.32)$ and fruit shape index $(-0.27)$. These positive and negative effects may result from the competition among plants for photoassimilates, as well as the competition between vegetative growth and fruiting, caused by high planting density. The yield was positively correlated with fruit weight $(0.34)$ and the leaf area index $(0.52)$ but negatively correlated with leaf area $(0.31)$ and fruit shape index (0.26). The fresh-fruit weight was negatively correlated with the leaf area index (-0.26) and soluble solids (-0.32).

Thus, with the increase in planting density, plants may have reached a critical level, where the increase in production per plant was not be compensated by specific values of the leaf area, leading to decreased productivity. The positive effects observed on the production per plant demonstrates that increases in the photosynthetic rates, mean fruit mass, and therefore the production per plant, result in increased productivity. Regarding the negative effects, it was observed that the greater the production per plant, the lower the leaf area index and the effect on the fruit shape index.
According to Peil et al. (2014), the increase in productivity of denser cultivations is due to increased interception of the photosynthetically active light and higher levels of photosynthesis, which stimulates plant growth, increases total photoassimilates, and favors fruit growth.

\section{Materials and Methods}

\section{Experimental site and climate conditions}

The experiment was carried out in a greenhouse in the Sector of Vegetable Crops and Aromatic Medicinal Plants, Universidade Estadual Paulista (UNESP), Faculty of Agriculture and Veterinary Sciences (FCAV), Jaboticabal ( $21^{\circ} 14^{\prime} 05^{\prime \prime}$ S, 48 $48^{\circ} 17^{\prime} 09^{\prime \prime}$ W; 614 m a.s.l.), São Paulo, Brazil. The climate, according to the Köppen classification, is Aw (tropical savanna) in transition to Cwa (temperate with dry winter and hot summer).

Monthly mean temperature and relative humidity $(\mathrm{RH})$ in the greenhouse during the trial period were as follows: $37^{\circ} \mathrm{C}$ and $54 \% \mathrm{RH}$ in March, $24^{\circ} \mathrm{C}$ and $77 \% \mathrm{RH}$ in April, and $21^{\circ} \mathrm{C}$ and $75 \%$ RH in May.

\section{Experimental design and plant material}

Treatments were arranged in a randomized complete block design, with $5 \times 3$ factorial treatments with four replicates. Five mini watermelon hybrids (Beni Kodama, Ki Kodama, Smile, New Kodama, and Beni Makura) and three plant spacing configurations $\left(\mathrm{E}_{1}=0.35 \mathrm{~m}, \mathrm{E}_{2}=0.50 \mathrm{~m}\right.$, and $\mathrm{E}_{3}=$ $0.65 \mathrm{~m}$ ) were evaluated. Each plot consisted of 10 plants; six central plants in each plot were evaluated.

The hybrids have the following characteristics. Beni Kodama is a mini watermelon with round- shaped fruit, red flesh and a crunchy and fine texture and thin skin, resulting in optimal flesh utilization; the average fruit weight ranges from 1.50 to $2.00 \mathrm{~kg}$ (Sakama, 2015). Ki Kodama is a mini watermelon with light-green skin color, yellow flesh, and high soluble solids content; fruits also have thin skin, resulting in optimal flesh utilization (Sakama, 2015). Smile is an Ice Box-type hybrid, with oval fruits with dark-red flesh, excellent flavor, and soluble solids content ranging from 12 to $13{ }^{\circ}$ Brix (TAKII, 2015). New Kodama, a Kodama-type hybrid, has rounded fruit, yellow-crunchy flesh, and excellent flavor $\left(10-12{ }^{\circ} \mathrm{Brix}\right)$, and the fruit weight ranges from 0.80 to $1.00 \mathrm{~kg}$ (TAKII, 2015). Beni Makura is a mini watermelon with slightly elongated fruit shape, average weight of 2.00 $\mathrm{kg}$, thin skin, and the flesh is red, very sweet, and with very few seeds (TAKII, 2015).

\section{Experimental protocol}

Seedlings were grown from seeds sown in 128-cell polystyrene trays filled with substrate Bioplant ${ }^{\circledR}$ (Bioplant, Bioplant Agricola Ltda, Nova Ponte, MG, Brazil), with one seed per cell. The trays were placed in a greenhouse and irrigated three to four times a day. The seedlings were transplanted at the first true-leaf stage into plots.

Mini watermelon plants were placed into $13-\mathrm{dm}^{3}$ polypropylene pots, one seedling per pot, which were filled with coconut husk fiber (Golden Mix 98 ${ }^{\circledR}$, Amafibra, Ananindeua, PA, Brazil). A drip irrigation system was used throughout the crop cycle, providing a nutrient solution recommended for fruit-type vegetables, with the following

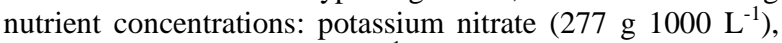

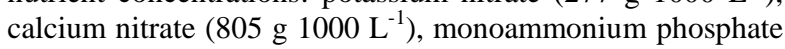




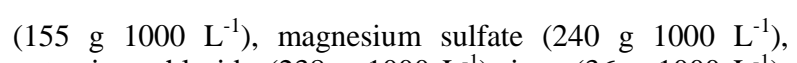

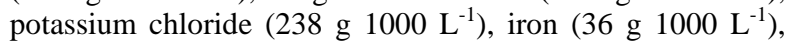

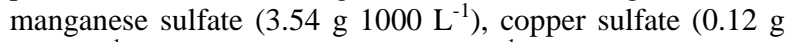

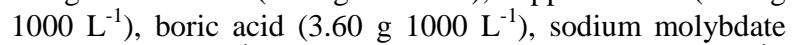

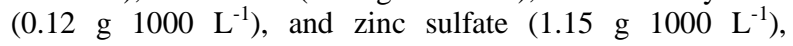
according to Furlani et al. (1999).

The pots were arranged in double rows, with spacing of $1.00 \mathrm{~m}$ between the double rows and $0.80 \mathrm{~m}$ between rows within the double rows. Spacing between the plants followed the description as aforementioned. The stems were trained on polythene plastic strings and pinched at $2.20 \mathrm{~m}$ height. Secondary stems were trimmed up to the 8 th node.

Bee hives (Melipona sp.) were placed into the greenhouse for pollination during the early flowering stage. The fruits were thinned, and two fruits were kept per plant. When the fruits reached approximately the size of an orange fruit, they were placed into netted nylon bags. The control of pests and diseases was developed as necessary, following the technical recommendations for watermelons.

\section{Harvest and evaluation of the characteristics}

Harvesting was conducted twice, on May 9, 2014, and May 24,2014 , when the fruits reached maximum size, loss of brightness and their skin texture changed (Almeida, 2006); fruits were evaluated for growth characteristics, production, and quality.

Several growth characteristics and parameters associated with production were evaluated. Net photosynthetic rate (A) was measured with a portable infrared gas analyzer (IRGA, model LCpro-SD; ADC, Herts, England) 33 days after the transplantation of the seedlings. Leaf area $\left(\mathrm{cm}^{2}\right.$ plant $\left.{ }^{-1}\right)$ was determined using a LI-COR area meter (model LI 3000; Lincoln, NE, USA) at the end of the production cycle. The leaf area index (LAI) was calculated as the ratio between the leaf area and the area assigned to each plant according to the spacing among plants. Shoot dry mass was calculated as the mean shoot dry mass of the plants from each plot, and fresh fruit weight $(\mathrm{g})$ was expressed as the mean fruit weight in the plot. The yield $\left(\mathrm{t} \mathrm{ha}^{-1}\right)$ for each plant was inferred from the mean weight of the fruits and spacing between the plants and rows, and production per plant $\left(\mathrm{kg} \mathrm{plant}^{-1}\right)$ consisted of the sum of fruit weights per plant.

Characteristics regarding fruit quality were also evaluated. Transverse and longitudinal diameters $(\mathrm{mm})$ were measured on five fruits per plot using a digital caliper. Firmness was calculated as the mean of two measurements that were conducted at the middle region of the skin with a penetrometer model (FT 327, QA Supplies, Virginia, USA) set up with an 8-mm tip, and the results were expressed in Newton $(\mathrm{N})$. Fruit shape index was determined as the ratio between the means of longitudinal and transverse fruit diameters. Soluble solids (SS) were measured in five fruits per plot with a digital refractometer, and the values expressed in ${ }^{\circ}$ Brix were adjusted to $20^{\circ} \mathrm{C}$ (AOAC, 1997). To determine titrable acidity, the flesh was homogenized in $10 \mathrm{~mL}$ of distilled water and this homogenate was then titrated with $0.05 \mathrm{~N} \mathrm{NaOH}$ (AOAC, 1997). Maturation index (SS/TA), calculated as the ratio between soluble solids and acidity, was used to assess the stage of maturity and fruit flavor (Chitarra and Chitarra, 2005).

\section{Statistical analysis}

Analysis of variance was performed and the means were compared by Tukey test $(\mathrm{P}<0.05)$. Pearson correlation analysis between the hybrids and spacing was also performed using the statistical program AGROESTAT (Barbosa and Maldonado Jr., 2015).

\section{Conclusion}

In thus study, despite the established competition in terms of spacing, the performance of hybrids was not negatively affected, and all could be used for growing in a greenhouse with coconut shell fiber. In relation to the spacings used, it is recommended the spacing of $0.50 \mathrm{~m}$, since it is possible greater fruit development (fresh fruit mass, transverse and longitudinal diameter) and fruit quality (firmness and solids solids) also facilitating the plant management techniques.

\section{Acknowledgments}

The first author acknowledges the support by the Fundação de Amparo a Pesquisa do Estado de São Paulo (FAPESP), Brazil (grant no. 2013-05587-0).

\section{References}

Agrianual (2015) Anuário da agricultura brasileira. FNP Consultoria e Comércio, São Paulo.

Almeida D (2006) Manual de culturas hortícolas Vol. II. Editorial Presença, Lisboa.

Andriolo JL, Espínola MCG, Godói R, Bortolotto OC, Luz GL (2004) Crescimento e produtividade de plantas de tomateiro em cultivo protegido sob alta densidade e desfolhamento. Ciênc Rural. 34: 1251-1253.

AOAC International (1997) Official methods of analysis of the Association of Official Analytical Chemists 16th ed. Gaithersburg, Md. AOAC International.

Barbosa JC, Maldonado Jr W (2015) Experimentação agronômica \& agroestat - sistema para análises estatísticas de ensaios agronômicos. Multipress, Jaboticabal.

Campagnol R, Mello SC, Barbosa JC (2012) Vertical growth of mini watermelon according to the training height and plant density. Hortic Bras. 30: 726-732.

Castro CRT, Garcia R (1996) Competição entre plantas com enfase no recurso luz. Ciênc Rural. 26: 167-174.

Chitarra MIF, Chitarra AB (2005) Pós-colheita de frutas e hortaliças: fisiologia e manuseio. 2. ed. UFLA, Lavras.

Dias RCS, Lima MAC (2010) Colheita e pós colheita. In: Sistema de produção de melancia. Embrapa Semiárido. Versão Eletrônica. Available at: http://sistemasdeproducao.cnptia.embrapa.br/FontesHTML/ Melancia/SistemaProducaoMelancia/colheita.htm.

Accessed in December 2015.

Dias RCS, Silva CMJ, Queiróz MA, Costa ND, Souza FF, Santos MH, Paiva LB, Barbosa GS, Medeiros KN (2006) Desempenho agronômico de linhas de melancia com resistência ao oídio. Available at http://www.abhorticultura.com.br/biblioteca/arquivos/Dow nload/Biblioteca/46_0351.pdf. Acessed in November 2014.

Furlani PR, Silveira LCP, Bolonhezi D, Faquim V (1999) Cultivo hidropônico de plantas. Instituto Agronômico, Campinas.

Gonsalves MVI, Pavani LC, Cecílio Filho AB, Feltrim AL (2011) Índice de área foliar e produtividade da melancieira com frutos sem sementes em função do espaçamento entre plantas e de $\mathrm{N}$ e $\mathrm{K}$ aplicados por fertirrigação. Rev Científica. 39: 25-33.

Goreta S, Perica S, Dumicic G, Bucan L, Zanic K (2005) Growth and yield of watermelon on polyethylene mulch with different spacing and nitrogen rates. HortScience. 40: 366-369. 
Grangeiro LC, Pedrosa JF, Neto FB, Negreiros MZ (1999) Qualidade de híbridos de melão amarelo em diferentes densidades de plantio. Hortic Bras. 17: 110-113.

IEA (2014) Instituto de Economia Agrícola e Coordenadoria de Assistência Técnica Integral. Available at: http://www.iea.sp.gov.br. Accessed in November 2014.

Kultur F, Harrison HC, Staub JE (2001) Spacing and genotype affect fruit sugar concentration, yield, and fruit size of muskmelon. HortScience. 36: 274-278.

Malik MA, Saleem MF, Aziz A, Jehanzeb (2004) Agrophysiological response of canola (Brassica napus L.) to different planting patterns and stand densities. Pak J Life Soc Sci. 2: 148-152.

Papadopoulos AP, Pararajasingham S (1997) The influence of plant spacing on light interception and use in greenhouse tomato (Lycopersicon esculentum Mill.): a review. Sci Hortic. 69: 1-29.

Peil RMN, Albuquerque Neto AAR, Rombaldi CV (2014) Densidade de plantio e genótipos de tomateiro cereja em sistema fechado de cultivo em substrato. Hortic Bras. 32: 234-240.

Pereira FHF, Nogueira ICC, Pedrosa JF, Negreiros MZ, Bezerra Neto F (2003) Poda da haste principal e densidade de cultivo sobre a produção e qualidade de frutos em híbridos de melão. Hortic Bras. 21: 191-196.

Pretty KM (1982) O potássio e a qualidade da produção agrícola In: Yamada T, Igue K, Muzilli O, Usherwood NR (eds.) Potássio na agricultura brasileira. Associação Brasileira da Potassa e do Fosfato, Piracicaba. pp. 177-194.

Purquerio LFV, Cecílio Filho AB (2005) Concentração de nitrogênio na solução nutritiva e número de frutos sobre a qualidade de frutos de melão. Hortic Bras. 23: 831-836.

Ramos ARP, Dias RCS, Aragão CA (2009) Densidades de plantio na produtividade e qualidade de frutos de melancia. Hortic Bras. 27: 560-564.

Resende GM, Costa ND (2003) Características produtivas da melancia em diferentes espaçamentos de plantio. Hortic Bras. 21: 695-698.
SAKAMA (2015) Produtos. Available at: http://www.sementesakama.com.br/produtos.asp. Accessed in August 2015.

Salisbury FB, Ross CW (1985) Plant Physiology, 3rd ed. Wadsworth Publishing Company, Belmont.

Sangoi L, Silva PRF, Argenta G, Horn D (2003) Bases morfofisiológicas para aumentar a tolerância de cultivares de milho a altas densidades de plantas In: IV Reunião Técnica Catarinense de Milho e Feijão, Lages, p.19-24.

Seabra Júnior S, Pantano SC, Hidalgo AH, Rangel MG, Cardoso AII (2003) Avaliação do número e posição de frutos de melancia produzidos em ambiente protegido. Hortic Bras. 21: 708-711.

Silva HR, Carrijo OA, Marouelli WA, Reis NVB (1998) Competição de cultivares de pepino tipo 'Japonês' sob cultivo protegido e a campo aberto. Hortic Bras. 16: 314. 10: $1-5$.

TAKII (2015) Melancia. Available at: http://www.takii.com.br/melancia.html. Accessed in September 2015. 